\title{
Endoscopic Diagnosis in Ascaris lumbricoides Case with Pyloric Obstruction
}

\author{
Pilor Obstrüksiyonlu Ascaris lumbricoides Vakasında Endoskopik Tanı
}

\author{
Kemal Peker ${ }^{1}$, Kemal Kılıç² \\ 'Department of General Surgery, Palandöken State Hospital, Erzurum, Turkey \\ ${ }^{2}$ Department of Surgery, Faculty of Medicine, Kafkas University, Kars, Turkey
}

\begin{abstract}
Ascaris lumbricoides is the largest and most prevalent helminth seen in the human body. Ascariasis having high morbidity and mortality causes a unique type of intestinal obstruction with specific problems. This is probably due to reduced intestinal absorption and luminal obstruction, which can lead to anorexia and blockage of the absorbing surface. It affects humans especially in developing countries. This essay presented a 78- year- old female case had severe abdominal pain, nausea and constipation for seven days and the pylorus was obstructed by A. lumbricoides and diagnosis was obtained by endoscopy. During endoscopy in the treatment, the ascariasis that could be removed was. Afterwards, $100 \mathrm{mg}$ mebendazole was given for 3 days once in two months. The purpose of the presentation of this case is that it is seen in advanced ages and it sets us thinking of stomach tumor due to its obstruction and anemia clinic.(Turkiye Parazitol Derg 2011; 35: 210-3)
\end{abstract}

Key Words: Ascaris lumbricoides, pyloric obstruction, anemia

Received: 05.06.2011

Accepted: 30.09 .2011

\section{ÖZET}

Ascaris lumbricoides insanda görülen en büyük ve en yaygın helminttir. Ascariasis yüksek morbidite ve mortaliteye sahip belirli sorunlarla birlikte olan intestinal tıkanmanın özgün bir tipine neden olur. Bu lümen tıkanıklığının, muhtemelen azalmış intestinal emilime, iştahsızlığa ve emici yüzey azalmasına yol açmış olabileceği düşünülmektedir. A. lumbricoides özellikle az gelişmiş ülkeleri etkilemektedir. Bu makalede, yedi gündür devam etmekte olan şiddetli karın ağrısı, bulantı ve konstipasyon şikayeti olan ve tanısı endoskopi ile konan, pilorun A. lumbricoides ile obstrüksiyona uğradığı 78 yaşında bayan vaka sunulmuştur. Tedavisinde endoskopi işlemi sırasında çıkarılabilinen askariasisler çıkarıldı. Takiben 100 mg mebendazol 3 gün süre ile iki ayda bir kez verildi. Bu vakayı taktim etmemizdeki amaç vakanın ileri yaşlarda görülmesi, yapmış olduğu obstrüksiyon ve anemi kliniği ile mide tümörünü düşündürmesidir. (Turkiye Parazitol Derg 2011; 35: 210-3)

Anahtar Sözcükler: Ascaris lumbricoides, pilor obstrüksiyonu, anemi

Kabul Tarihi: 30.09.2011

\section{INTRODUCTION}

Ascaris lumbricoides is the most common helminth affecting humans and causing important medical and social problems especially in developing countries (1-3). A. lumbricoides is a parasitic infection that can be seen in all age groups, mostly in children. In our country, the frequency of ascariasis incidence varies between $0.05-45 \%$ in the regions where there are infrastructure problems and night soil is used as fertilizer (4). In Isparta, a province in Turkey, A. lumbricoides rate was found $1.3 \%$ in a study including 800 pediatric patients. In Van, also a province in Turkey, while the rate was $21.97 \%$ (5) in a study performed on 132 pregnant women, A. lumbricoides was not found in a study in the eskişehir province (6). A. lumbricoides infestation occurs in all age groups but is more common in children at preschool age (7). This infection is very common in the tropics and subtropics. Patients with ascariasis can be asymptomatic or

Address for Correspondence / Yazışma Adresi: Dr. Kemal Peker, Department of General Surgery, Palandöken State Hospital, Erzurum, Turkey Phone: +90 4423156851 E-mail: surgery16@windowslive.com doi:10.5152/tpd.2011.53 
may present with different clinical features in the form of simple nausea, decreased appetite, abdominal pain or more severe bowel obstruction, perforation, intussusception, biliary colic etc. Ultrasonography (USG) can be a quick, safe, noninvasive and relatively inexpensive tool in diagnosing the presence of worms and also evaluating response to treatment (8). Diagnosis can be obtained by seeing eggs in stool, larvas in pituitary or worms in the anus, mouth and nose (4). Most of the patients have been successfully treated conservatively. Mebendazole use is advised especially for patients who are at risk of increased intestinal obstruction (9). Iron deficiency affects people more worldwide than any other form of malnutrition, and its control is a global priority in public health. Iron deficiency anemia results from a variety of causes, including inadequate iron intake, high physiologic demands in early childhood and pregnancy, and iron losses from parasitic infections. The relative importance of these causes and appropriate strategies for prevention of iron deficiency anemia differs between populations and age groups (10).

Different types of helminth infection may affect growth in different ways,- absorption, voluntary intake of food and degree of mucosal damage. The nutritional status of the host may be impaired by the increased nutrient demands of the parasite itself or by specific actions such as blockage of the absorbing surface of the mucosa by adult $A$. lumbricoides worms. This infection is more likely to influence the nutritional status of children and adolescents (11).

The purpose of the presentation of this case is that it is seen in advanced ages and it sets us thinking of stomach tumor due to its obstruction and anemia clinic.In addition,our aim is to draw attention to the clinical course of the disease and to probe the etiology of pyloric obstruction even if the latter is a rare cause.

\section{CASE PRESENTATION}

A 78-year-old Turkish woman with severe abdominal pain and vomiting and progressive constipation for seven days was admitted to the emergency department. Her past medical history was

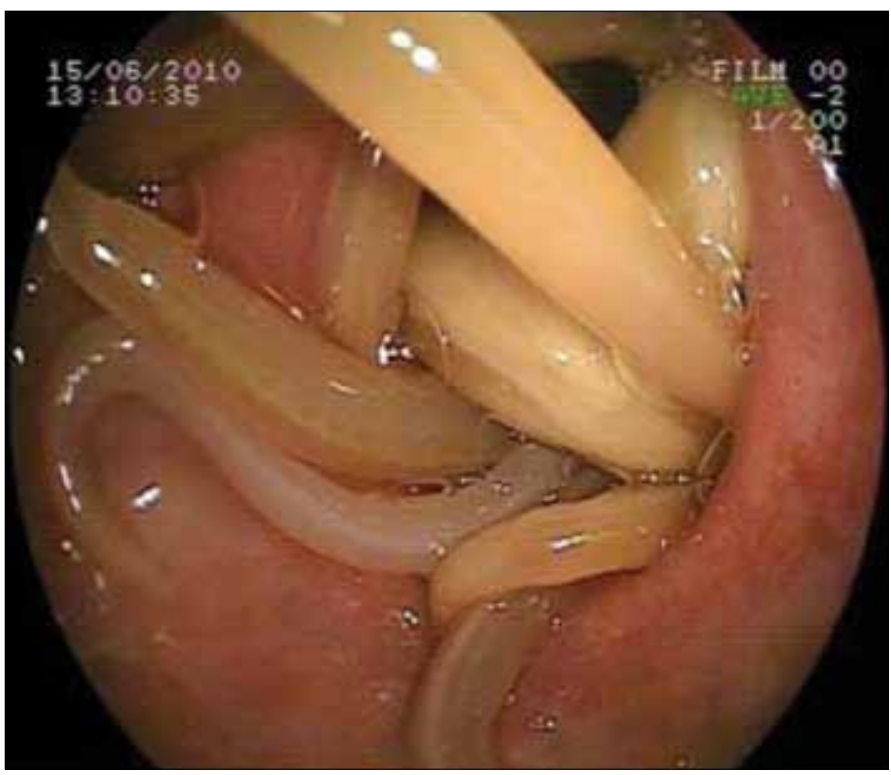

Figure 1. Ascariasis having obstructed pylorus non-contributory apart from a weight loss of about $10 \mathrm{~kg}$ over a 3 month period. Physical examination revealed abdominal tenderness and rigidity. X-ray was normal. Abdominal USG was also reported as normal. Rectal examination showed neither stool nor masses. Laboratory findings showed a white blood cell count WBC of 8,700 $\mu \mathrm{L}$, haemoglobin (Hb) $10.1 \mathrm{gr} / \mathrm{dL}, \mathrm{HCT} 34.7, \mathrm{MCV}$ $68 \mathrm{fl}, \mathrm{MCH} 25.3 \mathrm{pg}, \mathrm{MCHC} 37 \mathrm{~g} / \mathrm{dL}, \mathrm{RDW} 12.3$ and platelets $148.000 \mu \mathrm{L}$, serum sodium $123 \mathrm{mmol} / \mathrm{L}$, potassium $5.0 \mathrm{mmol} / \mathrm{L}$, chloride $97 \mathrm{mmol} / \mathrm{L}$, and creatinine $62 \mathrm{~mol} / \mathrm{L}$. Gastroscopy in patients who vomit did not pass the distal pylorus because the pylorus was blocked by AL (Figure 1-3).

The diagnosis of our patient was established with endoscopic views and confirmed by the views of parasite eggs in the rectal swab. A case with similar clinical findings with capsular endos-

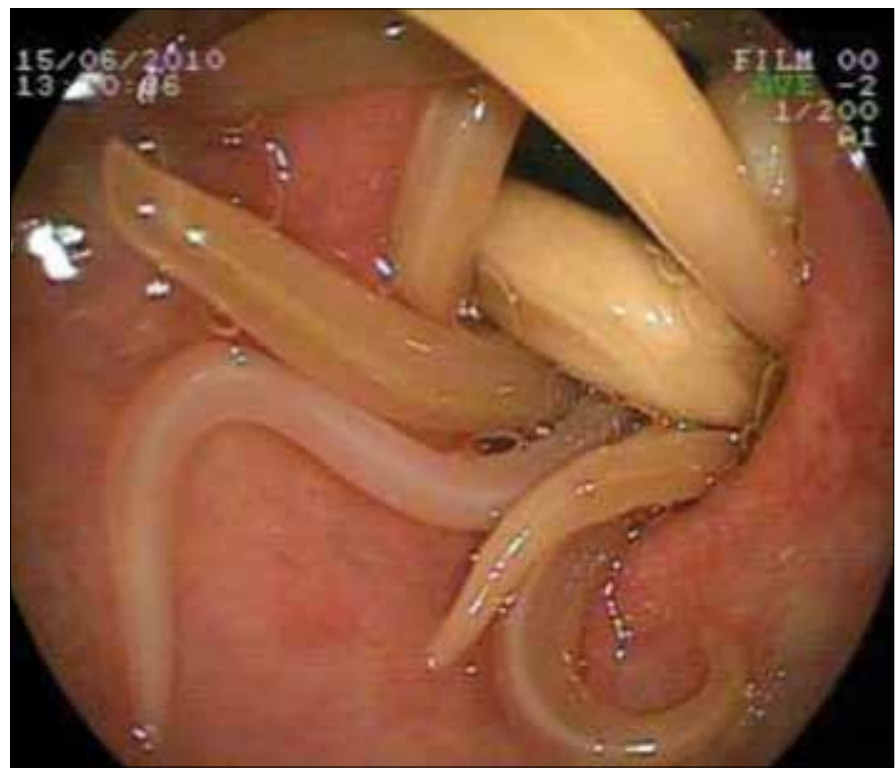

Figure 2. Live ascariasis changing its position from the first picture into this one

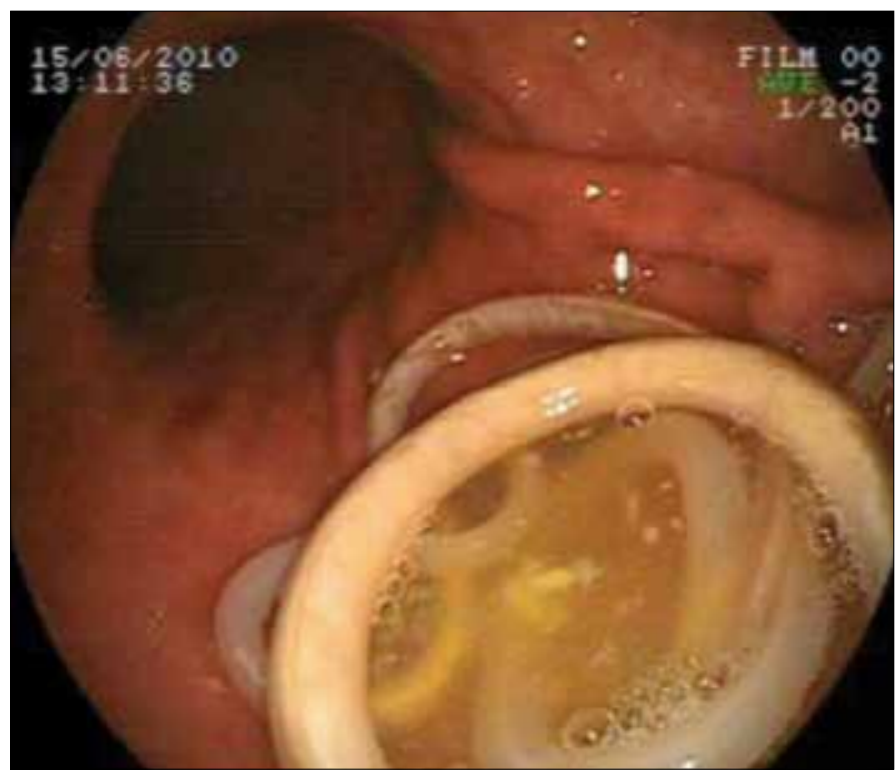

Figure 3. Live ascariasis in stomach antrum-corpus 
copy was defined by A. Flierman and et al. (12). This study was carried out in the general surgery clinic in Palandöken State hospital in Erzurum. This study was approved by the Ethics Committee of Kafkas University of Kars and performed according to the Declaration of Helsinki. During endoscopy ascariasis that could be removed was removed. Afterwards, $100 \mathrm{mg}$ mebendazole was given for 3 days once in two months. In this period, it was observed that the patient passed a large amount of ascariasis in her stool. On the other hand,preexisting anemia was treated with ferroglycine sulfate. There were no signs of relapse during 6 months of follow-up. The haemoglobin level gradually normalized and remained normal in the following months.

\section{DISCUSSION}

Ascariasis is one of the most common intestinal parasite infections of human beings and it is calculated that one fourth of the world population is infected. Over 1.4 billion people are infected throughout the world. Fortunately, Ascaris-related severe clinical disease is restricted to heavy worm overload in only about 2 million people, leading to 20.000 deaths per year in endemic areas (13). The highest prevalence of ascariasis occurs in tropical countries where warm and wet climates provide environmental conditions that favour year-round transmission of infection. Transmission occurs mainly via ingestion of water or food (particularly raw vegetables or fruit) contaminated with A. lumbricoides eggs and occasionally via inhalation of contaminated dust. Adult worms inhabit the lumen of the small intestine, usually in the jejunum or ileum (12).

Their location area extends from the stomach to the ileocecal valve without causing any serious symptoms (14). When the environment changes to be intolerable for them to live, they migrate to more appropriate areas of the intestinal tract. A. lumbricoides may cause serious problems during this migration including pancreatitis, cholecystitis, liver abscess, intestinal obstruction and even perforation (15).

Most infected people are asymptomatic and this disease occurs after the stools of those people and the eggs that are passed out are taken orally. After the eggs are ingested orally, pathology continues as 1) pulmonary phase, 2) intestinal phase and 3) complications (16). About 3 months after the pulmonary phase, mature male and female worms that settle into the intestine may cause serious complications such as pancreatitis, cholangitis, hepatic abscess, acute appendicitis, volvulus, invagination, intestinal perforation and granulamatous peritonitis in the small intestines. They may rarely cause pyloric obstruction, as they may in our patient (16-18).

The most frequent presentation of $A$. lumbricoides infection is intermittent colicky abdominal pain and incomplete bowel obstruction. When mechanical obstruction persists, a bolus of the worm acts like a fixed point and leads to intussusception or volvulus. Our patient presented with the complaint of vomiting, abdominal pain and constipation which started 7 days ago. She continued vomiting after she was hospitalized. That the patient had weight loss in the past three months as well as vomiting set us thinking of the probability of pyloric obstruction. Blood and biochemical studies had no special value. Direct abdominal graphy was normal.

Ultrasonographic images are quite important in diagnosis $(19,20)$. There were no pathological ultrasonographic findings in our patient. The number of helminthes is the most important factor to determine the clinical fate of the disease. Infected patients with no complete intestinal obstruction can be treated conservatively. Among the methods are IV fluid treatment, nasogastric aspiration, oral piperazine, hypertonic saline and normal saline. However, a large number of ascaris may cause complete or nearly complete intestinal obstruction, combining and forming a glomus (17). In our case, ascaris obstructed the pylorus completely by forming a glomus. During endoscopy, transition was assured by removing the ascaris that could be removed. Afterwards, conservative treatment was continued. Ascaris may also excrete neurotoxins and anaphylatoxins leading to small bowel spasticity and inflammation. These toxins may induce mechanical obstruction, as well $(21,22)$.

Heavy infection results in a tangle of adult worms producing a partial intestinal obstruction. In children, incomplete intestinal obstruction by an A. lumbricoides worm bolus is usually benign, as more than $80 \%$ of it resolves spontaneously on conservative treatment with bowel rest, antispasmodics, analgesics and intravenous fluids (23). Further complications of persistent intestinal obstruction, perforation, segmental volvulus, and more rarely, intussusception require surgical intervention (2). Volvulus and ischemic bowel, two of the most serious intestinal complications, account for less than $10 \%$ of cases (23). It is compulsory to recognize these complications expeditiously and to initiate early and aggressive management.

In conclusion, A. lumbricoides should be kept in mind as it occurs in all age groups but is more common in children at preschool age with sudden-acute intestinal obstruction. Although acariasis is more prevalent in tropical and subtropical climates and is rare in developed countries, the physician should be aware of the case and he/she should pay attention to this disease in patients with anemia. Early diagnosis and treatment are essential to minimize morbidity and mortality.

\section{Conflict of Interest}

No conflict of interest was declared by the authors.

\section{REFERENCES}

1. Chawla A, Patwardhan V, Maheshwari M, Wasnik A. Primary ascaridial perforation of the small intestine: Sonographic diagnosis. J Clin Ultrasound 2003; 31: 211-3. [CrossRef]

2. Akgun Y. Intestinal obstruction caused by ascaris lumbricoides. Dis Colon Rectum 1996; 39: 1159-63. [CrossRef]

3. Philip J, Chico M, et al. Human infection with Ascaris. J Infect Dis 2000; 182: 1207-13.

4. Sönmez Tamer G, Tamer Y. Case report: an intestinal obstruction due to ascariasis. Turkiye Parazitol Derg 2009; 33: 185-7.

5. Yılmaz H, Gül A, Dilek i, Göz Y. Hamile Kadınlarda Barsak Parazitozlarının Dağııımı. Van Tıp Dergisi 1999; 6: 1.

6. Doğan N, Demirüstü C, Aybey A. The prevalence of intestinal parasites according to the distribution of the patients' gender and parasite species for five years at the Osmangazi University Medical Faculty. Turkiye Parazitol Derg 2008; 32: 120-5. 
7. Steinberg R, Davies J, Millar AJ, Brown RA, Rode H. Unusual intestinal sequelae after operations for ascaris lumbricoides infestation. Pediatr Surg Int 2003; 19: 85-7.

8. Sharma UK, Rauniyar RK, Bhatta N. Roundworm infestation presenting as acute abdomen in four cases--sonographic diagnosis. Kathmandu Univ Med J (KUMJ) 2005; 3: 87-90.

9. Türk $E$, Dölek N. Ascaris lumbricoides'in neden olduğu barsak tıkanıklığı: nadir görülen bir olgu. Gülhane Tıp Dergisi 2010; 52: 225-8.

10. Stoltzfus RJ, Chwaya HM, Tielsch JM, Schulze KJ, Albonico M, Savioli L. Epidemiology of iron deficiency anemia in Zanzibari Schoolchildren: the importance of hookworms. Am J Cl in Nutr 1997; 65: 153-9

11. Jardim-Botelho A, Brooker S, Geiger SM, Fleming F, Souza Lopes $A C$, Diemert DJ, et al. Age patterns in undernutrition and helminth infection in a rural area of Brazil: associations with ascariasis and hookworm. Trop Med Int Health 2008; 13: 458-67. [CrossRef]

12. Flierman A, Koornstra JJ, Weersma RK. An unexpected cause of iron deficiency detected by capsule endoscopy. Neth J Med 2009; 67: 247-8.

13. Khuro MS. Ascariasis. Gastroenterol Clin N Am 1996; 25: 553-76. [CrossRef]

14. Hershkovitz D, Wasserberg N. Large bowel obtrruction due to Ascaris lumbricoides. Isr Med Assoc J 2004; 6: 115-6.

15. Yetim I, Ozkan OV, Semerci E, Abanoz R. Rare cause of intestinal obstruction, Ascaris lumbricoides infestation: two case reports. Cases J 2009; 2: 7970. [CrossRef]
16. Arman D. Solunum sistemi infeksiyonları. Ekim N (ed). Paraziter Akciğer İnfeksiyonları. İstanbul: Turgut Yayıncılık ve Ticaret AŞ, 2001: 283-309.

17. Gangopadhyay AN, Upadhyaya VD, Gupta DK, Sharma SP, Kumar V. Conservative treatment for round worm intestinal obstruction. Indian J Pediatr 2007; 74: 1085-7. [CrossRef]

18. Ekingen $G$, Kahraman $H$, Gürbüz $Y$, Güvenç $B H$. Çocukta nadir bir olgu: parazitik bezoara bağlı intestinal obstrüksiyon. Gazi Medical Journal 2004; 15: 157-9.

19. Cole GJ. Surgical manifestations of ascaris lumbricoides in the intestine. Br J Surg 1965, 52: 444-7. [CrossRef]

20. Steinberg R, Davies J, Millar AJ, Brown RA, Rode H. Unusual intestinal sequelae after operations for Ascaris lumbricoides infestation. Pediatr Surg Int 2003; 19: 85-7.

21. Villamizar E, Méndez M, Bonilla E, Varon H, de Onatra S. Ascaris lumbricoides infestation as a cause of intestinal obstruction in children: experience with 87 cases. J Pediatr Surg 1996; 31: 201-4. [CrossRef]

22. de Silva NR, Guyatt HL, Bundy DA. Worm burden in intestinal obstruction caused by Ascaris lumbricoides. Trop Med Int Health 1997; 2: 189 -90. [CrossRef]

23. Rode H, Cullis S, Millar A, Cremin B, Cywes S. Abdominal complications of Ascaris lumbricoides in children. Pediatr Surg Int 1990; 5: 397-401. [CrossRef] 